\title{
Wpływ zabiegów zoo- i fitomelioracyjnych na aktywność biologiczną gleby pod zalesieniami na gruntach porolnych
}

\author{
Anna Augustyniuk-Kram ${ }^{1 *}$, Karol J. Kram² \\ ${ }^{1}$ Instytut Ekologii i Bioetyki, Wydział Filozofii Chrześcijańskiej \\ Uniwersytet Kardynała Stefana Wyszyńskiego w Warszawie, ul. Wóycickiego 1/3, 01-938 Warszawa \\ ${ }^{2}$ Kampinoski Park Narodowy, ul. Tetmajera 38, 05-080 Izabelin \\ *a.kram@uksw.edu.pl
}

\begin{abstract}
Streszczenie
W Polsce zalesienia zwykle prowadzi się na najsłabszych glebach, wyłączonych z użytkowania rolniczego i nieużytkach, czyli tzw. gruntach porolnych. Cechą charakterystyczną takiego siedliska jest słabej jakości gleba, dosyć wysoka zawartość składników pokarmowych dla drzew, w szczególności azotu, a także niewielki poziom próchniczy. Ma to znaczenie dla jakości zachodzących w glebach porolnych procesów mikrobiologicznych. Restytucja lasu na takim siedlisku wymaga stosowania różnych zabiegów rekultywacyjnych, polepszających warunki glebowe, zwiększających aktywność biologiczną i żyzność gleby. W artykule przedstawiono wyniki długoterminowego eksperymentu dotyczącego skuteczności różnych zabiegów zoo- i fitomelioracyjnych na zalesianych gruntach porolnym po ponad 30 latach od ich zastosowania w borach sosnowych w północno-zachodniej Polsce. Zabiegi te polegały na wprowadzeniu do gleby dodatkowej materii organicznej w postaci kory i trocin, wysiano łubin oraz introdukowano faunę glebową. Powierzchnią porównawczą dla zalesień na glebach porolnych w przedstawionym eksperymencie była powierzchnia na glebach leśnych, zlokalizowana na takim samym siedlisku, w drzewostanie sosnowym, w tym samym wieku. Aktywność biologiczną gleby mierzono aktywnością enzymów glebowych dehydrogenaz i kwaśnej fosfatazy, mierzono biomasę mikroorganizmów, a także określono zawartość całkowitego rozpuszczonego węgla i azotu.
\end{abstract}

\section{Stowa kluczowe}

zalesienia, grunty porolne, aktywność gleby, zoo- i fitomelioracja

\section{Wstęp}

Zalesianie gruntów porolnych i nieużytków jest jednym z głównych działań i sposobów zwiększania lesistości naszego kraju w ramach Krajowego Programu Zwiększania Lesistości (Web-o1). Okres najintensywniejszych zalesień gruntów porolnych, w tym również procesów sukcesji naturalnej zbiorowisk leśnych, przypadł na lata 1946-1970, kiedy przeciętnie rocznie zalesiano 37 tys. ha. W kolejnych latach rozmiar zalesień był mniejszy i utrzymywał się na poziomie od 12 tys. ha w latach 1971-199o do blisko 17 tys. ha rocznie w latach 1991-2003. Od roku 2004 do 2013 średnia powierzchnia zalesień wyniosła 9,o tys. ha rocznie (Web-o1). Doprowadziło to do wzrostu lesistości naszego 
kraju z 20,8\% w 1945 r. do poziomu $29,5 \%$ w roku 2016 (Web-02).

Restytucja lasu na gruntach porolnych jest procesem trudnym $\mathrm{z}$ uwagi na specyficzne warunki siedliskowo-glebowe będące wynikiem długoletniego rolniczego użytkowania gleby (Gorzelak 1996, Sobczak 1996, Krawczyk 2014). Cechą charakterystyczną takiego siedliska jest słabej jakości gleba, gruba warstwa (podeszwa) płużna powstająca na skutek wieloletniej orki, utrudniająca przenikanie wody i przebicie korzeni w głąb profilu glebowego (Szujecki 1990). Ponadto, w glebach porolnych w porównaniu z glebami leśnymi jest dosyć wysoka zawartość składników odżywczych, w szczególności azotu, w pierwszych latach upraw leśnych. Gleby porolne są mniej kwaśne niż typowe gleby leśne. Ma to znaczenie dla jakości zachodzących w glebach porolnych procesów mikrobiologicznych. W glebach porolnych poziom próchniczy jest zazwyczaj niewielki, a proces rozkładu materii organicznej (głównie celulozy) w glebie porolnej oparty jest na aktywności bakterii, podczas gdy w glebach typowo leśnych opiera się na czynnym udziale grzybów rozkładających ligninę (Rykowski 1990, Tuszyński 1990).

To, co aktualnie wiemy o drzewostanach na gruntach porolnych, o ich zdrowotności i kondycji oraz jakie modele i strategie zalesiania należy stosować w zależności od siedliska jest rezultatem szczegółowych badań i długoterminowych eksperymentów prowadzonych przez leśników i naukowców (Sobczak 1990, Oszako i Olejarski 2003, Sierota 2011). Przedstawione w tej pracy wyniki otrzymano podczas długoterminowego eksperymentu założonego i koordynowanego przez Katedrę Ochrony Lasu i Ekologii SGGW w Warszawie, a dotyczącego oceny skuteczności wybranych zabiegów zoo- i fitomelioracyjnych po 30 latach od ich zastosowania w borach sosnowych na gruntach porolnych (Web-o3).

\section{Materiał i Metody}

\subsection{Opis eksperymentu i terenu badań}

Powierzchnię eksperymentalną (PE) założono jesienią 1976 roku w oddziale $79 \mathrm{~m}$ (aktualnie 104Ag i 8oc) nadleśnictwa Niedźwiady (leśnictwo Kamionka) w województwie pomorskim na nieużytku rolniczym na obszarze 1,44 ha $(120 \times 120 \mathrm{~m})$ (Webo3). Obszar ten został podzielony na 6 pasów o wymiarach $120 \times 20 \mathrm{~m}$ i zaorany. $\mathrm{Na}$ pierwszym, trzecim i piątym pasie wykonano orkę głęboką do $40 \mathrm{~cm}$, natomiast na drugim, czwartym i szóstym orkę płytką do głębokości $20 \mathrm{~cm}$. Wiosną 1977 roku każdy z pasów podzielono poprzecznie na 3 części $(A, B, C)$, każda po $800 \mathrm{~m}^{2}$ i zastosowano różne zabiegi zoo- i fitomelioracyjne. Poletka C pokryto korą sosnową i trocinami w ilości $48 \mathrm{~m}^{3}$ kory i $24 \mathrm{~m}^{3}$ trocin i zaorano co $1,5 \mathrm{~m}$ w kierunku prostopadłym do kierunku orki pełnej i posadzono jednoroczną sosnę co $1 \mathrm{~m}$. W podobny sposób zaorano i zalesiono poletka A i B z tym, że po zalesieniu na poletkach A rozsiano w międzyrzędy łubin trwały, natomiast poletka B pozostawiono jako kontrolę (Fig. 1). W takim układzie eksperyment „trwał” do wiosny 1981 roku, kiedy to na poletka $\mathrm{z}$ wyjątkiem $\mathrm{A}_{3}$, $\mathrm{B}_{3}, \mathrm{C}_{3}, \mathrm{~A}_{4}, \mathrm{~B}_{4}, \mathrm{C}_{4}$ introdukowano krocionoga Proteroiulus fuscus (750 osobników na każde poletko) - saprofaga biorącego udział w rozkładzie kory i procesach humifikacji (Tracz 1984).

Dodatkowo do badań wytypowano zewnętrzną powierzchnię kontrolną (ZPK) na glebach leśnych. ZPK zlokalizowana była na takim samym siedlisku oraz w drzewostanie sosnowym w tym samym wieku jak na powierzchni eksperymentalnej PE (Web-o3).

\subsection{Analizy fizyko-chemiczne i biologiczne gleby}

Glebę do analiz z terenu badań pobrano trzykrotnie: 26 IV, 7 VII i 27 X 2012 r. Próby pobierano przy pomocy armatki glebowej (o średnicy $5 \mathrm{~cm}$ ) z głębokości $10 \mathrm{~cm}$. Za każdym razem pobierano po 5 próbek glebowych z 18 poletek na powierzchni eksperymentalnej (PE) oraz po 5 próbek 


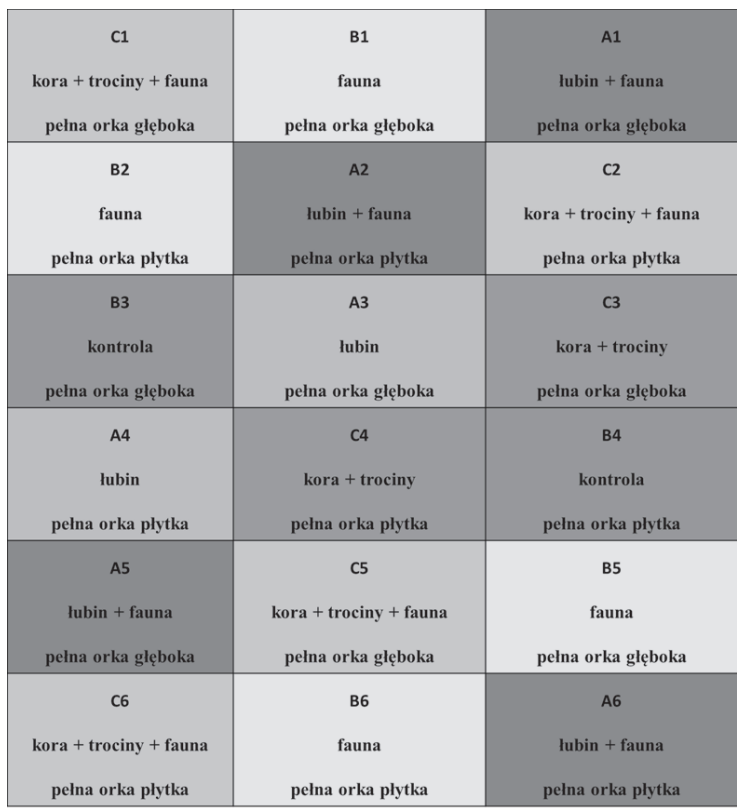

Fig.1. Schemat poletek na powierzchni eksperymentalnej z opisem wariantów doświadczenia

z 3 stanowisk na glebach leśnych zwanych zewnętrzną powierzchnią kontrolną (ZPK) (Fig. 1). Łącznie w każdym terminie pobrano po 105 próbek glebowych i każdą próbkę analizowano oddzielnie..

Bezpośrednio po przywiezieniu próbek do laboratorium mierzono koncentrację całkowitego rozpuszczonego węgla (TDC) i całkowitego rozpuszczonego azotu (TDN), aktywność dehydrogenaz (Dha), aktywność kwaśnej fosfatazy (APh) oraz oddychanie gleby indukowane glukozą SIR (Substrate Induced Respiration) w celu określenia biomasy drobnoustrojów. Zawartość całkowitego rozpuszczonego węgla (total disolved carbon - TDC) i całkowitego rozpuszczonego azotu (total dissolved nitrogen - TDN) wykonywano w ekstraktach wodnych. Próbki gleby ważono, zalewano $300 \mathrm{ml}$ wody destylowanej, wytrząsano przez $1 \mathrm{~h}$ i filtrowano przez filtr nylonowy. Przed analizą próby filtrowano dodatkowo przez filtr teflonowy o wielkości porów o,45 $\mu \mathrm{m}$. Zawartość całkowitego rozpuszczonego węgla i całkowitego rozpuszczonego azotu określono przy użyciu analizatora Formacs ${ }^{\mathrm{HT}}$ TOC/TN Analyser (SKALAR Analytical,
Holandia) i wyrażono w mg na kg suchej masy gleby.

Aktywność dehydrogenaz oznaczano w próbkach gleb o naturalnej wilgotności według metody Casida et al. (1964). Jako substrat zastosowano chlorek 2,3,5 trifenylotetrazoliowy (TTC), który ulega przekształceniu do trifenyloformazanu (TPF). Próbki gleby z substratem inkubowano w temp. $30^{\circ} \mathrm{C}$ przez 20 godzin. Absorbancję TPF (w $\mu \mathrm{g} / \mathrm{ml}$ ) mierzono spektrofotometrycznie wobec etanolu przy długości fali $485 \mathrm{~nm}$. Aktywność dehydrogenazy badanych próbek gleby wyrażona została w $\mu \mathrm{g} \mathrm{TPF} / \mathrm{g}$ suchej masy gleby. Aktywność kwaśnej fosfatazy oznaczano według metody Tabatabai i Bremnera (1969). Jako substrat zastosowano roztwór p-nitrofenylofosforanu sodu (PNP) w buforze o $\mathrm{pH}=6,5$. Próby inkubowano w temp. $37^{\circ} \mathrm{C}$ przez $1 \mathrm{~h}$. Absorbancję uwolnionego p-nitrofenolu ( $\mathrm{w} \mu \mathrm{g} / \mathrm{ml}) \mathrm{mie}$ rzono spektrofotometrycznie przy długości fali 400 nm. Aktywność kwaśnej fosfatazy badanych próbek gleby wyrażona została w mg p-nitrofenolu/g suchej masy gleby/h. Biomasę drobnoustrojów (micC) oznaczono metodą pomiaru respiracji indukowanej 
substratem (Substrate Induced Respiration) (Anderson i Domsch 1978). Jako substratu użyto glukozę (30 mg/g gleby) w ilości wywołującej maksymalną respirację mikroorganizmów. Próby inkubowano w temp. $22^{\circ} \mathrm{C}$. Ilość uwalnianego $\mathrm{CO}_{2}$ mierzono aparatem IRGA (Infra-Red Gas Analyzer) co godzinę przez $5 \mathrm{~h}$. Biomasę drobnoustrojów wyrażono ilością węgla (C) pochodzenia mikroorganizmalnego (micC) w mg na g suchej masy gleby.

\subsection{Analiza statystyczna wyników}

Wyliczono średnie arytmetyczne oraz ich odchylenia standardowe. Testowano wpływ orki (orka płytka, orka głęboka), zabiegu (kontrola, fauna, kora i trociny, kora, trociny i fauna, łubin, łubin i fauna) oraz sezonu badań (wiosna, lato, jesień).

Dla każdego analizowanego czynnika przeprowadzono jednoczynnikową analizę wariancji (ANOVA). Istotność różnic dla poszczególnych zmiennych analizowano testem Tukeya przy $\mathrm{p}<0,05$. Różnice $\mathrm{w}$ badanych parametrach pomiędzy powierzchnią eksperymentalną a zewnętrzną powierzchnią kontrolną w poszczególnych sezonach testowano stosując nieparametryczny test Manna-Whitneya (Utest). Obliczono również współczynnik korelacji dla następujących parametrów: aktywność dehydrogenaz, kwaśnej fosfatazy, biomasy mikroorganizmów, zawartości całkowitego rozpuszczonego węgla i azotu. Analizy statystyczne wykonano przy użyciu pakietu IBM SPSS Statistics.

\section{Wyniki}

Po upływie ponad 30. lat rodzaj zastosowanej orki (płytka i głęboka) przed zalesieniem gruntów porolnych na powierzchni eksperymentalnej nie miał wpływu na badane parametry gleby. Porównując z zewnętrzną powierzchnią kontrolną parametry takie jak aktywność kwaśnej fosfatazy oraz biomasa mikroorganizmów na powierzchni eksperymentalnej były na podobnym poziomie. Stwierdzono natomiast, że koncentracja całkowitego rozpuszczonego węgla i całkowitego rozpuszczonego azotu była ponad dwukrotnie wyższa w glebie zewnętrznej powierzchni kontrolnej w porównaniu z glebą powierzchni eksperymentalnej poddanej orce. Z kolei aktywność dehydrogenaz była niższa w glebie zewnętrznej powierzchni kontrolnej w porównaniu z poddaną orce powierzchnią eksperymentalną (Tab. 1).

Z pięciu zastosowanych na powierzchni eksperymentalnej zabiegów melioracyjnych najlepszy efekt osiągnięto w wariancie kora-trociny-fauna. Dla tego wariantu stwierdzono istotnie wyższą koncentrację całkowitego rozpuszczonego węgla i całkowitego rozpuszczonego azotu oraz podwyższoną aktywność kwaśnej fosfatazy w porównaniu $\mathrm{z}$ wariantem kontrolnym, gdzie nie wzbogacono gleby przed zalesieniem dodatkową ilością materii organicznej, ani nie wprowadzono dodatkowej fauny w postaci krocionoga. Zastosowane zabiegi nie miały natomiast wpływu na aktywność dehydrogenaz i biomasę mikroorganizmów (Tab. 2). Mimo zastosowanego zabiegu na powierzchni eksperymentalnej, w glebie zewnętrznej powierzchni kontrolnej koncentracja całkowitego rozpuszczonego węgla była półtora razy większa niż w najkorzystniejszym wariancie kora-trociny-fauna i aż trzy i pół razy większa niż w wariancie łubin oraz łubin-fauna (Tab. 2). W wariancie kora-trociny-fauna koncentracja całkowitego rozpuszczonego azotu była na takim samym poziomie jak w glebie zewnętrznej powierzchni kontrolnej, natomiast w pozostałych wariantach eksperymentu całkowitego rozpuszczonego azotu było od dwóch do sześciu razy mniej niż w glebie zewnętrznej powierzchni kontrolnej (Tab. 2). Aktywność kwaśnej fosfatazy w glebie zewnętrznej powierzchni kontrolnej była tylko nieznacznie niższa niż w glebie z wariantu kora-trociny-fauna i na podobnym poziomie jak w pozostałych wariantach nawożenia (Tab. 2).

Sezon miał wpływ na badane parametry gleby i wpływ ten był różny w zależności od powierzchni badawczej. Koncentracja 
Tabela 1. Właściwości gleby w zależności od zastosowanej orki przed zalesieniem na powierzchni eksperymentalnej (PE) oraz porównanie z zewnętrzną powierzchnią kontrolną (ZPK) (w tabeli podano wartości średnie \pm odchylenie standardowe; wartości w poszczególnych kolumnach $\mathrm{z}$ wariantów PE oznaczone tą samą literą nie różnią się istotnie statystycznie przy p<0,05)

\begin{tabular}{lccccc}
\hline $\begin{array}{c}\text { Warianty } \\
\text { PE }\end{array}$ & $\begin{array}{c}\text { TDC } \\
{[\mathrm{mg} / \mathrm{kg}]}\end{array}$ & $\begin{array}{c}\text { TDN } \\
{[\mathrm{mg} / \mathrm{kg}]}\end{array}$ & $\begin{array}{c}\text { Dha } \\
{[\mu \mathrm{g} \mathrm{TPF} / \mathrm{g}]}\end{array}$ & $\begin{array}{c}\text { APh } \\
{[\mathrm{mg} / \mathrm{g} / \mathrm{h}]}\end{array}$ & $\begin{array}{c}\mathrm{micC} \\
{[\mathrm{mg} / \mathrm{g}]}\end{array}$ \\
\hline orka płytka & $71,40 \pm 32,97 \mathrm{a}$ & $2,73 \pm 1,98 \mathrm{a}$ & $10,85 \pm 5,90 \mathrm{a}$ & $2,93 \pm 1,06 \mathrm{a}$ & $0,63 \pm 0,09 \mathrm{a}$ \\
orka głęboka & $67,92 \pm 34,80 \mathrm{a}$ & $2,70 \pm 0,22 \mathrm{a}$ & $7,52 \pm 4,05 \mathrm{a}$ & $2,34 \pm 1,35 \mathrm{a}$ & $0,62 \pm 0,09 \mathrm{a}$ \\
\hline ZPK & $175,02 \pm 125,49$ & $5,46 \pm 7,08$ & $5,47 \pm 2,56$ & $2,67 \pm 1,26$ & $0,63 \pm 0,083$ \\
\hline
\end{tabular}

Tabela 2. Właściwości gleby w zależności od zastosowanego zabiegu przed zalesieniem na powierzchni eksperymentalnej (PE) oraz porównanie z zewnętrzną powierzchnią kontrolną (ZPK) (w tabeli podano wartości średnie \pm odchylenie standardowe; wartości w poszczególnych kolumnach $\mathrm{z}$ wariantów PE oznaczone tą samą literą nie różnią się istotnie statystycznie przy $\mathbf{p}<0,05)$

\begin{tabular}{lccccc}
\hline $\begin{array}{c}\text { Warianty } \\
\text { PE }\end{array}$ & $\begin{array}{c}\text { TDC } \\
{[\mathrm{mg} / \mathrm{kg}]}\end{array}$ & $\begin{array}{c}\text { TDN } \\
{[\mathrm{mg} / \mathrm{kg}]}\end{array}$ & $\begin{array}{c}\text { Dha } \\
{[\mu \mathrm{g} \mathrm{TPF} / \mathrm{g}]}\end{array}$ & $\begin{array}{c}\mathrm{APh} \\
{[\mathrm{mg} / \mathrm{g} / \mathrm{h}]}\end{array}$ & $\begin{array}{c}\text { micC } \\
{[\mathrm{mg} / \mathrm{g}]}\end{array}$ \\
\hline Kontrola & $64,47 \pm 27,69 \mathrm{a}$ & $1,44 \pm 1,92 \mathrm{a}$ & $6,13 \pm 3,30 \mathrm{a}$ & $1,80 \pm 0,59 \mathrm{a}$ & $0,59 \pm 0,05 \mathrm{a}$ \\
Fauna & $61,47 \pm 30,30 \mathrm{a}$ & $2,67 \pm 2,04 \mathrm{a}$ & $7,52 \pm 5,46 \mathrm{a}$ & $1,91 \pm 0,53 \mathrm{a}$ & $0,62 \pm 0,09 \mathrm{a}$ \\
Kora-trociny & $77,67 \pm 19,98 \mathrm{a}$ & $2,82 \pm 1,71 \mathrm{a}$ & $12,10 \pm 7,18 \mathrm{a}$ & $3,01 \pm 1,61 \mathrm{a}$ & $0,72 \pm 0,15 \mathrm{a}$ \\
Kora, trociny, fauna & $116,37 \pm 32,37 \mathrm{~b}$ & $5,52 \pm 1,92 \mathrm{~b}$ & $12,72 \pm 4,93 \mathrm{a}$ & $3,89 \pm 1,29 \mathrm{~b}$ & $0,62 \pm 0,08 \mathrm{a}$ \\
kubin & $52,83 \pm 20,76 \mathrm{a}$ & $2,82 \pm 0,39 \mathrm{a}$ & $9,52 \pm 4,23 \mathrm{a}$ & $2,96 \pm 1,08 \mathrm{a}$ & $0,61 \pm 0,06 \mathrm{a}$ \\
kubin-fauna & $45,15 \pm 20,16 \mathrm{a}$ & $1,08 \pm 1,11 \mathrm{a}$ & $7,14 \pm 3,83 \mathrm{a}$ & $2,24 \pm 0,86 \mathrm{a}$ & $0,59 \pm 0,04 \mathrm{a}$ \\
\hline ZPK & $175,02 \pm 125,49$ & $5,46 \pm 7,08$ & $5,47 \pm 2,56$ & $2,67 \pm 1,26$ & $0,63 \pm 0,083$ \\
\hline
\end{tabular}

całkowitego rozpuszczonego węgla (TDC) w próbkach gleby z zewnętrznej powierzchni kontrolnej w porównaniu z próbkami gleby z powierzchni eksperymentalnej była wyższa w każdym z trzech sezonów badawczych, jednak w odróżnieniu od próbek z powierzchni eksperymentalnej najwyższą koncentrację węgla stwierdzono latem a nie wiosną, i była ona istotnie wyższa $(\mathrm{p}=\mathrm{o}, \mathrm{o} 3)$ od tej stwierdzonej w glebie z powierzchni eksperymentalnej (Fig. 2). Najwyższą koncentracja całkowitego rozpuszczonego azotu (TDN) w próbkach gleby z zewnętrznej powierzchni kontrolnej, podobnie jak w przypadku węgla stwierdzono latem i była ona istotnie wyższa $(\mathrm{p}=\mathrm{O}, 03)$ od tej stwierdzonej w glebie powierzchni eksperymentalnej. Wiosną i jesienią koncentracja całkowitego rozpuszczalnego azotu była na podobnym poziomie (Fig. 2). Aktywność dehydrogenaz (Dha) w próbkach gleby z zewnętrznej powierzchni kontrolnej w trzech badanych sezonach była niższa w porównaniu z powierzchnią eksperymentalną, z tym, że były to różnice nieistotne statystycznie (Fig. 2). Nie stwierdzono również istotnych różnic w aktywności kwaśnej fosfatazy (APh) oraz w biomasie mikroorganizmów (micC) w próbkach gleby pomiędzy powierzchnią eksperymentalną i zewnętrzną powierzchnią kontrolną $\mathrm{w}$ żadnym $\mathrm{z}$ badanych sezonów (Fig. 2).

W glebie powierzchni eksperymentalnej nie stwierdzono istotnej korelacji pomiędzy aktywnością dehydrogenaz, kwaśnej fosfatazy i biomasy mikroorganizmów a koncentracją całkowitego rozpuszczonego węgla i azotu oraz pomiędzy biomasą mikroorganizmów a aktywnością dehydrogenaz i kwaśnej fosfatazy, natomiast w glebie zewnętrznej powierzchni kontrolnej wykazano istotną dodatnią korelację pomiędzy aktywnością kwaśnej fosfatazy a koncentracją całkowitego rozpuszczonego węgla oraz 

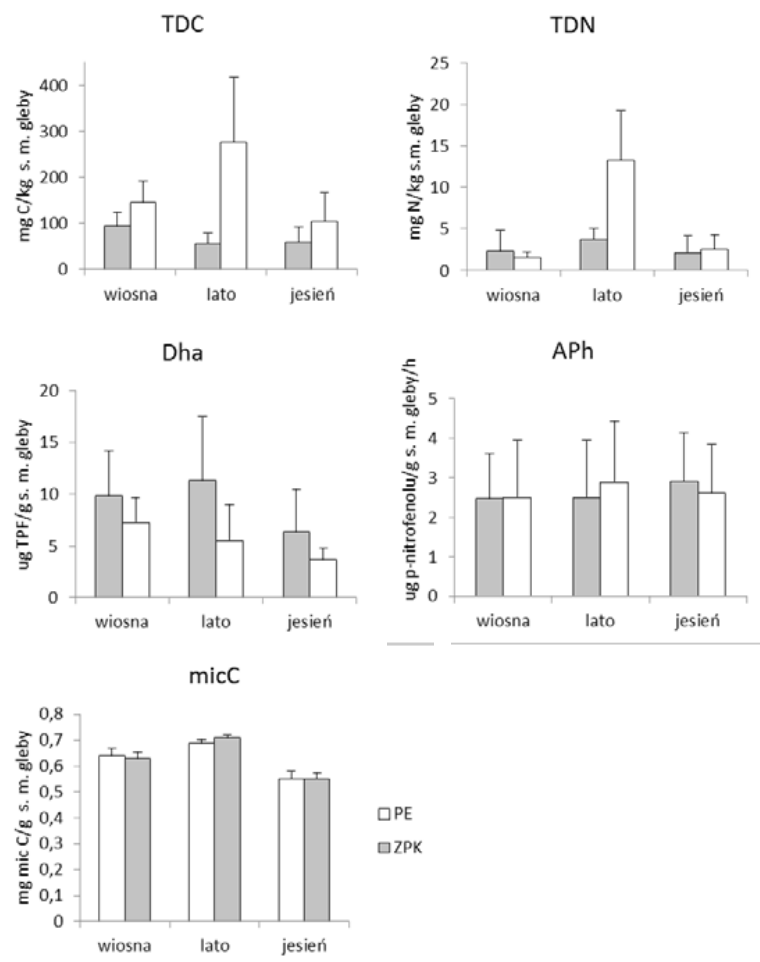

Fig. 2. Porównanie badanych parametrów aktywności biologicznej gleby na powierzchni eksperymentalnej (PE) i zewnętrznej powierzchni kontrolnej (ZPK) w trzech sezonach badawczych

biomasą mikroorganizmów a koncentracją całkowitego rozpuszczonego węgla i azotu (Tab. 3).

\section{Dyskusja}

W ekosystemach leśnych gleba jest tym elementem siedliska, który decyduje o jego produktywności, wpływa na tempo wzrostu i rozwoju drzew, a także na budowę i właściwości drewna (Jelonek et al. 2010, Tomczak i Jelonek 2013). Jako wskaźniki bezpośredniej aktywności, a tym samym żyzności gleby stosuje się najczęściej pomiar aktywności enzymatycznej, biomasy i aktywności drobnoustrojów, a także zawartości węgla i azotu w glebie (Nannipieri et al. 1990, Kieliszewska-Rokicka 2001, Olszowska et al. 2005). Gleba rolna różni się zasadniczo od gleby leśnej (Richards 1974, Tuszyński 1990), a zmiana sposobu jej użytkowania z rolniczego na typowo leśne wpływa na jej właściwości fizyko-chemiczne i biologiczne
(Gorzelak 1996, Kahle et al. 2005, Olszewska i Smal 2008, Smal i Olszewska 2008). Jednakże w opinii niektórych autorów, nawet po upływie ponad 30 lat od zalesienia gleba pod zalesieniem jest nadal pod pewnymi względami bardziej podobna do gleby ornej niż leśnej, a drzewostany na takich gruntach narażone są na działanie niekorzystnych czynników chorobotwórczych i szkodników (Rykowski 1990, Smal i Olszewska 2008, Sierota 2013). Zwoliński (1998) uważa, że właściwości fizyko-chemiczne gleby zmieniają się dopiero po 30 latach w glebach użytkowanych w sposób typowo leśny. Następuje wówczas wymywanie organicznych związków węgla do warstwy mineralnej gleby i tworzenie się poziomu próchnicznego. Mniejsza zawartość organicznego węgla i azotu w zalesionych glebach porolnych wynika natomiast z dużego ich pobierania z gleby podczas intensywnego wzrostu drzew w pierwszych latach po zalesieniu. 
Tabela 3. Korelacja pomiędzy aktywnością enzymatyczną i biomasą mikroorganizmów a koncentracją całkowitego rozpuszczonego węgla i azotu w glebie powierzchni eksperymentalnej i zewnętrznej powierzchni kontrolnej

\begin{tabular}{ccccc}
\hline powierzchnia & parametry & $\begin{array}{c}\text { TDC } \\
{[\mathrm{mg} / \mathrm{kg}]}\end{array}$ & $\begin{array}{c}\text { TDN } \\
{[\mathrm{mg} / \mathrm{kg}]}\end{array}$ & $\begin{array}{c}\text { micC } \\
{[\mathrm{mg} / \mathrm{g}]}\end{array}$ \\
\hline \multirow{2}{*}{ PE } & Dha $[\mu \mathrm{g} \mathrm{TPF} / \mathrm{g}]$ & $0,264^{\text {n.i. }}$ & $0,313^{\text {n.i. }}$ & $0,335^{\text {n.i. }}$ \\
& APh $[\mathrm{mg} / \mathrm{g} / \mathrm{h}]$ & $0,250^{\text {n.i. }}$ & $0,261^{\text {n.i. }}$ & $0,037^{\text {n.i. }}$ \\
& micC $[\mathrm{mg} / \mathrm{g}]$ & $0,172^{\text {n.i. }}$ & $0,251^{\text {n.i. }}$ & - \\
\multirow{2}{*}{ ZPK } & Dha $[\mu \mathrm{TPF} / \mathrm{g}]$ & $0,196^{\text {n.i. }}$ & $0,033^{\text {n.i. }}$ & $0,251^{\text {n.i. }}$ \\
& APh $[\mathrm{mg} / \mathrm{g} / \mathrm{h}]$ & $0,746^{*}$ & $0,529^{\text {n.i. }}$ & $0,309^{\text {n.i. }}$ \\
& micC $[\mathrm{mg} / \mathrm{g}]$ & $0,825^{\text {** }}$ & $0,791^{\text {** }}$ & - \\
\hline
\end{tabular}

n.i. - współczynnik korelacji nieistotny statystycznie dla poziomu istotności o,o5

* - współczynnik korelacji istotny statystycznie przy poziomie istotności o,o5

** - współczynnik korelacji istotny statystycznie przy poziomie istotności o,o25

*** - współczynnik korelacji istotny statystycznie przy poziomie istotności o,o1

Potwierdzają to również nowsze badania, w których stwierdzono, że koncentracja rozpuszczonego organicznego węgla i azotu zmniejsza się w głąb profilu glebowego $(\mathrm{Qu}-$ alls et al. 2000, Lars et al. 2010), ale jest to jednocześnie uzależnione od wieku drzewostanów. Generalnie im starszy drzewostan, tym koncentracja rozpuszczalnej frakcji materii organicznej (dissolved organic matter), w skład której wchodzi rozpuszczalny węgiel i azot, rośnie, gdyż głównym jej źródłem w glebie jest warstwa nagromadzonej ściółki (Justine et al. 2017).

W przedstawionych badaniach stwierdzono ponad 2,5-krotnie wyższą zawartość całkowitego rozpuszczonego węgla i ponad 3,5-krotnie wyższą zawartość całkowitego rozpuszczonego azotu w glebie zewnętrznej powierzchni kontrolnej (glebie leśnej) w porównaniu z zalesioną glebą orną (w wariancie kontrolnym) (Tab. 2). Podobne wyniki otrzymali w swoich badaniach Bielińska i Hury (2009), gdzie naturalne gleby leśne, pod około 150 letnimi drzewostanami sosnowymi, zawierały około 2-krotnie więcej węgla organicznego i około 1,5-krotnie więcej całkowitego azotu niż gleby porolne po 15-17 latach od zalesienia sosną. Smal et al. (2004) stwierdzili natomiast, że zalesienie gleb porolnych wpłynęło na wzrost stężenia węgla organicznego, zwłaszcza w poziomie próchniczym, w porównaniu z sąsiadującymi glebami pola uprawnego i jego zawartość generalnie rosła wraz z wiekiem drzewostanów (38, 54 i 70-letnim). Potwierdzają to również badania przeprowadzone przez Vesterdal et al. (2002) oraz Smal i Olszewską (2008). Ponadto w drzewostanach na glebach porolnych rozkład i mineralizacja nagromadzonej ściółki leśnej jest zbyt powolna w wyniku m.in. nadmiernego zakwaszenia gleby, czy też z powodu niewłaściwie ukształtowanej jeszcze mikroflory i mikrofauny glebowej, co zaburza krążenie materii w ekosystemie i zakłóca procesy akumulacji podstawowych biogenów w warstwie próchniczej (Michalski et al. 2006, Chapin et al. 2012).

Liczne badania wskazują na istnienie ścisłej zależności między aktywnością enzymów glebowych a zawartością węgla organicznego i ogólnego azotu (Andersson et al. 2004, Domżał i Bielińska 2007, Bielińska i Hury 2009). Jednocześnie zawartość węgla organicznego decyduje również o rozwoju i aktywności mikroflory glebowej będącej głównym źródłem wielu enzymów glebowych (Kieliszewska-Rokicka 2001). W przeprowadzonych przez nas badaniach w glebie powierzchni eksperymentalnej nie stwierdzono istotnej korelacji pomiędzy aktywnością dehydrogenaz, kwaśnej fosfatazy 
i biomasy mikroorganizmów a koncentracją całkowitego rozpuszczonego węgla i azotu oraz pomiędzy biomasą mikroorganizmów a aktywnością dehydrogenaz i kwaśnej fosfatazy. Natomiast w glebie leśnej zewnętrznej powierzchni kontrolnej wykazano istotną dodatnią korelację pomiędzy aktywnością kwaśnej fosfatazy a koncentracją całkowitego rozpuszczonego węgla oraz biomasą mikroorganizmów a koncentracją całkowitego rozpuszczonego węgla i azotu. Dane literaturowe podają, że aktywność dehydrogenaz jest ściśle związana $z$ odczynem gleby i z temperaturąa (Wolińska i Stępniewska 2012). Gleba zewnętrznej powierzchni kontrolnej charakteryzowała się niższym $\mathrm{pH}$ niż gleba porolna na powierzchni eksperymentalnej (Web-o3), co mogło mieć wpływ na obniżoną aktywność dehydrogenaz, natomiast podwyższona aktywność dehydrogenaz w okresie wiosenno-letnim mogła mieć związek z podwyższoną temperaturą wierzchniej warstwy gleby i wzrostem aktywności metabolicznej mikroorganizmów.

W przedstawionych badaniach istotne zwiększenie zawartości węgla i azotu na powierzchni eksperymentalnej osiągnięto po zastosowaniu wariantu nawożenia kora-trociny-fauna. Dla tego wariantu nawożenia stwierdzono również podwyższoną aktywność kwaśnej fosfatazy w porównaniu $\mathrm{z}$ wariantem kontrolnym, gdzie nie wzbogacono gleby przed zalesieniem dodatkową ilością materii organicznej, ani nie wprowadzono dodatkowej fauny glebowej. Fosfatazy katalizują rozkład organicznych form fosforu, które występują w glebie w postaci związków z materią organiczną, zwłaszcza $\mathrm{z}$ rozpuszczalnym węglem organicznym (Sapek 2014), stąd zapewne wynika podwyższona aktywność kwaśnej fosfatazy w tych wariantach, gdzie stwierdzono podwyższoną koncentrację węgla organicznego. Otrzymane przez nas wyniki potwierdzają wcześniejsze badania, które wskazywały na to, że kora oraz trociny, a także introdukcja fauny glebowej poprawiają właściwości gleby, zwiększają zawartość węgla i azotu w glebie, zwiększają aktywność mikroorganizmów
(Kwaśna i Sierota 1999, Kwaśna et al. 200o). Ponadto, jak wskazują badania innych autorów zmiana użytkowania gleby z rolniczej na leśną oraz wzbogacenie gleby poprzez wprowadzenie trocin prowadzi do przebudowy składu i struktury mikroorganizmów w kierunku rozwoju i dominacji grzybów nad bakteriami oraz zmian liczebności i różnorodności fauny glebowej, głównie akarofauny (Kwaśna i et al. 200o, Hedlund 2002, van der Wall et al. 2006, Klimek i Rolbiecki 2011), co w rezultacie znajduje odzwierciedlenie w niektórych parametrach fizykochemicznych i biologicznych gleby.

\section{Bibliografia}

Anderson J.P.E., Domsch K.H., 1978, A physiological method for the quantitative measurement of microbial biomass in soils, Soil Biology and Biochemistry, 10, 215-221.

Andersson M., Kjøller A., Struwe S., 2004, Microbial enzyme activities in leaflitter, humus and mineral soil layers in European forests, Soil Biology and Biochemistry, 36, 1527-1537.

Bielińska E.J., Hury G., 2009, Zastosowanie testów enzymatycznych do oceny jakości gleb porolnych zalesionych sosna zwyczajna/The Use of Enzymatic Tests in the Assessment of Post-Agricultural Soils Afforested with Common Pine, w: Stankowski S., Pacewicz K. (red.), „Tereny zdegradowane i rekultywowane - możliwości ich zagospodarowania", Wyd. P.P.H. Zapol Dmochowski, Sobczyk Sp.j., Szczecin, 7-15.

Casida L.E., Klein D.A., Santoro T., 1964, Soil dehydrogenase activity, Soil Science, 98, 371-376.

Chapin III, F.S., Matson P.A., Peter M.V., 2012, Decomposition and ecosystem carbon budgets: principles of terrestrial ecosystems ecology, Second edition. Springer-Verlag, New York, New York, USA.

Domżał H., Bielińska E.J., 2007, Ocena przeobrażeń środowiska glebowego i stabilności ekosystemów leśnych w obszarze oddziaływania Zaktadów Azotowych „Puławy” S.A., Acta Agrophysica, 145(2), 79-90.

Gorzelak A., 1996, Ekologiczne uwarunkowania ksztattowania lasów na gruntach porolnych, Sylwan, 140(5), 29-41.

Hedlund K., 2002, Soil microbial community structure in relation to vegetation management on former agricultural land, Soil Biology and Biochemistry, 34:1299-1307. 
Jelonek T., Pazdrowski W., Arasimowicz-Jelonek M., Tomczak A., 2010, Wtaściwości drewna sosny zwyczajnej (Pinus sylvestris L.) pochodzacej z gruntów porolnych, Sylwan, 154(5), 299-311.

Justine, M.F., Yang W., Wu F., Tan B., Khan M.N., Li Z., 2017, Dissolved organic matter in soils varies across a chronosequence of Pinus massoniana plantations, Ecosphere, 8(4):e01764. 10.1002/ecs2.1764.

Kahle P., Baum C., Boelcke B., 2005, Effect of afforestation on soil properties and mycorrhizal formation, Pedosphere, 15(6), 754-760.

Kieliszewska-Rokicka B., 2001, Enzymy glebowe i ich znaczenie w badaniach aktywności mikrobiologicznej gleby, w: Dahm H., Pokojska-Burdziej A. (red.), „Drobnoustroje środowiska glebowego, aspekty fizjologiczne, biochemiczne, genetyczne", Wyd. Adam Marszałek, Toruń, 37-47.

Klimek A., Rolbiecki S., 2011, Wzrost sosny zwyczajnej (Pinus sylvestris L.) i występowanie roztoczy (Acari) glebowych na rekultywowanym terenie popoligonowym w nadleśnictwie Żołędowo, Infrastruktura i Ekologia Terenów Leśnych, 1, 249-262.

Krawczyk R., 2014, Zalesienia a sukcesja wtórna, Leśne Prace Badawcze, 75(4), 423-427.

Kwaśna H., Sierota Z., 1999, Structure of fungal communities in barren post agricultural soil 1-and 2-years after pine sawdust application, Phytopathologica Polonica, 17, 13-21.

Kwaśna H., Sierota Z., Bateman G.L., 20oo, Fungal communities in fallow soil before and after amending with pine sawdust, Applied Soil Ecology, 14,177-182.

Lars R., Dan B.K., Maj B.J., 2010, Concentrations and fluxes of dissolved organic carbon and nitrogen in a Picea abies chronosequence on former arable land in Sweden, Forest Ecology and Management, 259, 275-285.

Michalski A., Sałek P., Płatek K., 2006, Zależność grubości ściótki od wieku drzewostanów sosnowych rosnacych na glebach porolnych i leśnych, Sylwan, 8, 20-25.

Nannipieri P., Grego S., Ceccanti B., 1990, Ecological significance of the biological activity in soil, in: Bollag J.M., Stotzky G. (eds), „Soil Biochemistry vol. 6", Dekker, New York, 293-355.

Olszewska M., Smal H., 2008, The effect of afforestation with Scots pine (Pinus sylvestris L.) of sandy post-arable soils on their selected properties. I. Physical and sorptive properties, Plant Soil, 305, 157-169.

Olszowska G., Zwoliński J., Matuszczyk I., Syrek D., Zwolińska B., Pawlak U., Kwapis Z., Dudzińska M., 2005, Wykorzystanie badań aktywności biologicznej do wyznaczenia wskaźnika żyzności gleb $w$ drzewostanach sosnowych na siedliskach boru świeżego i boru mieszanego świeżego, Leśne Prace Badawcze, 3, 17-37.

Oszako T., Olejarski I., 2003, Inicjowanie procesów przekształcania gleb porolnych $w$ gleby leśne poprzez wykorzystanie pozostałości zrębowych, kompostów i trocin, Prace IBL, Ser. A. (1), 76-79.

Qualls R.G., Haines B.L., Swank W.T., Tyler S.W., 200o, Soluble organic and inorganic nutrient fluxes in clearcut and mature deciduous forests, Soil Science Society of America Journal, 64, 1068-1077. Richards B.N., 1974, Introduction to the soil ecosystem, Longman Group Ltd., London, UK.

Rykowski K., 1990, Problemy ochrony lasu na gruntach porolnych/Problems of forest protection on afforested agricultural grounds, Sylwan, 134(3-12), 75-88.

Sapek B., 2014, Nagromadzanie i uwalnianie fosforu w glebach - źródła, procesy, przyczyny, Woda-Środowisko-Obszary Wiejskie, T. 14. Z. 1 (45), 77-10o. Sierota Z., 2011, Zmiany w środowisku drzewostanów sosnowych na gruntach porolnych $w$ warunkach przebudowy częściowej oraz obecności grzyba Phlebiopsis gigantea, Prace IBL; Rozprawy i monografie 17. Praca zbiorowa pod red. Z. Sieroty, ss. 279.

Sierota Z., 2013, Heterobasidion root rot in forests on former agricultural lands in Poland: Scale of threat and prevention, Scientific Research and Essays, 8(47), 2298-2305.

Smal H., Ligęza S., Olszewska M., 2004, Wptyw zalesienia piaszczystych gleb porolnych na jakość materii organicznej i skład chemiczny roztworu glebowego, Roczniki Gleboznawcze, 55(4), 139-148.

Smal H., Olszewska M., 2008, The effect of afforestation with Scots pine (Pinus silvestris L.) of sandy post-arable soils on their selected properties. II. Reaction, carbon, nitrogen and phosphorus, Plant Soil, 305, 171-187.

Sobczak R., 1990, Teoretyczne i praktyczne aspekty zaktadania upraw i prowadzenia drzewostanów na gruntach porolnych, Sylwan, 134(3-12), 61-74.

Sobczak R.O., 1996, Przywracaniu lasów na grunty porolne w Polsce, Sylwan, 140(5), 35-41.

Szujecki A., 1990, Ekologiczne aspekty odtwarzania ekosystemów leśnych na gruntach porolnych, Sylwan, 134(3-12), 23-40.

Tabatabai M. A., Bremner J.M., 1969, Use of p-nitrophenol phosphate for assay of soil phosphatase activity, Soil Biology and Biochemistry, 1, 301-307.

Tomczak A., Jelonek T., 2013, Promieniowa zmienność wtaściwości drewna sosny zwyczajnej (Pinus sylvestris L.) wyrostej na gruntach porolnych, Leśne Prace Badawcze, 74(2), 171-177.

Tracz H., 1984, Studies on the ecology of Proteroiulus fuscus (Am Stein 1857) (Diplopoda, Blaniulidae), Acta Zoologica Cracoviensia, 21, 519-576. 
Tuszyński M., 1990, Wtaściwości gleb porolnych a gospodarka leśna, Sylwan, 134(3-13), 41-50.

Wolińska A., Stępniewska Z., 2012, Dehydogenase Activity in Soil Ecosystem, in: Canuto R.A. (eds), „Dehydrogenases”, Intech, Rijeka,183-210.

Van der Wal A., van Veen J.A., Smant W., Boschker H.T.S., Bloem J., Kardol P., van der Putten W.H., de Boer W., 2006, Fungal biomass development in a chronosequence of land abandonment, Soil Biology and Biochemistry, 38, 51-60.

Vesterdal L., Ritter E., Gundersen P., 2002, Change in soil organic carbon following afforestation of former arable land, Forest Ecological Management, 169, 137-147.

Zwoliński J., 1998, Obieg węgla w borach sosnowych, Prace IBL (A), 862, 141-155.

(Web-01) Kaliszewski A., Wysocka-Fijorek E., Jabłoński M., Młynarski W., 2014, Aktualizacja krajowego programu zwiększania lesistości 2014. Synteza. Dokumentacja IBL, Warszawa. https:// nfosigw.gov.pl/download/gfx/nfosigw/pl/nfoekspertyzy/858/.../2013-772.pdf >, dostęp: 15.04.2018. (Web-o2) Zajączkowski G., Jabłoński M., Jabłoński T., Małecka M., Kowalska A., Małachowska J., Piwnicki J., 2017, Raport o stanie lasów w Polsce 2016. www.lasy.gov.pl/pl/informacje/.../do.../ lasy-w.../lasy...2016.../lasy_w_polsce_2016.pdf, dostęp: 29.04.2018.

(Web-o3) Tracz H., Aleksandrowicz-Trzcińska M., Augustyniuk-Kram A., Brzeziecki B, Drozdowski S., Kram K., Mazur S., Piętka J., Sławska M., Sławski M., Szujecki A., Tarabuła T., 2014, Ekosystem leśny na gruntach porolnych - ocena skuteczności wybranych zabiegów rekultywacyjnych po 30 latach od ich zastosowania $w$ borach sosnowych Polski ptn-zach (sprawozdanie końcowe) (dostęp: 29.04. 2018.)

\title{
The impact of revitalisation treatments on biological activity of soil under afforestation on post-agricultural land
}

\begin{abstract}
In Poland, afforestation is usually carried out on the weakest soils, excluded from agricultural use and wasteland, i.e. post-agricultural land. A characteristic feature of such a habitat is poor-quality soil, relatively high content of nutrients for trees, particularly nitrogen, as well as a low level of humus. This is important for the quality of microbiological processes occurring in post-agricultural soils. Restitution of the forest in such a habitat requires the use of various revitalisation treatments for improving soil quality and increasing biological activity and soil fertility. This article presents the results of a long-term experiment on the effectiveness of various revitalisation treatments (zo0- and phytomelioration) on afforested post-agricultural lands after more than 30 years from their application in pine forests in north-western Poland. These treatments consisted of introducing additional organic matter into the soil in the form of bark and sawdust, sowing lupine and introducing soil fauna. The comparative surface for afforestation on post-agricultural soils in the presented experiment was the area of forest soils, located in the same habitat, in a pine stand, at the same time. Soil biological activity was measured by the activity of soil enzymes dehydrogenases and acid phosphatase, the biomass of microorganisms was measured and the content of total dissolved carbon and nitrogen was also determined.
\end{abstract}

\section{Keywords}

afforestation, post-agricultural lands, soil quality, zoo- and phytomelioration 